\title{
Association Between Specific Indoor Air Pollutants and Pneumonia Episodes in Children Under Five in Abuja, Nigeria: A Case-control Study
}

Enemona Emmanuel Adaji ( $\square$ Emmanuel.Adaji@nottingham.ac.uk)

Division of Epidemiology and Public Health, School of Medicine University of Nottingham, UK https://orcid.org/0000-0001-5473-5043

\section{Michael Clifford}

Faculty of Engineering, University of Nottingham, UK.

\section{Jack Gibson}

Division of Epidemiology and Public Health, School of Medicine University of Nottingham, UK

\section{Magdalena Opazo Breton}

School of Health and Related Research (ScHARR), University of Sheffield.

\section{Revati Phalkey}

Division of Epidemiology and Public Health, School of Medicine University of Nottingham, UK

\section{Research}

Keywords: Indoor air pollution, Black Carbon, Particulate Matter, Carbon Monoxide, Pneumonia, Children under five, Low and middle income countries

Posted Date: August 26th, 2020

DOI: https://doi.org/10.21203/rs.3.rs-57371/v2

License: (c) (i) This work is licensed under a Creative Commons Attribution 4.0 International License. Read Full License 


\section{Abstract}

Background: Pneumonia causes most death in children under five globally. Indoor air pollution has been reported to increase the risk of children to pneumonia.

\section{Objective}

To investigate the association between specific indoor air pollutants and pneumonia episodes in children under five.

\section{Methods}

Using a case-control study design, we compared exposure of cases and controls to specific pollutants $\left(\mathrm{PM}_{2.5}, \mathrm{CO}, \mathrm{BC}\right.$ and $\left.\mathrm{PM}_{1}\right)$, using battery operated aerosol monitors. Data was analysed using Wilcoxon signed-rank test.

\section{Results}

The mean $\mathrm{PM}_{2.5}$ was higher in controls compared to cases. $\mathrm{PM}_{2.5}$ highest mean recorded for controls was $177 \mu \mathrm{g} / \mathrm{m}^{3}$. There was a significant difference between cases and controls for 10 hours ( $p$-value 0.0147$), 15$ hours ( $p$-value 0.0111 ) and $20-24$ hours ( $p$-value 0.0296$)$ for $\mathrm{PM}_{2.5}$.

No significant difference in $\mathrm{CO}$ concentration between cases and controls, the highest $\mathrm{CO}$ mean concentration recorded being $2930 \mu \mathrm{g} / \mathrm{m}^{3}$. Similarly, $\mathrm{PM}_{1}$ was consistently higher in controls compared to cases. However, this difference was not significant from exposure to $\mathrm{PM}_{1}$ between cases and controls $(P$ value>0.05), with the highest $\mathrm{PM}_{1}$ mean concentration recorded being $91 \mu \mathrm{g} / \mathrm{m} 3$.

There was a significant difference ( $p$-value 0.0260 ) in exposure to Black Carbon between cases and controls. $\mathrm{BC}$ was higher in households of cases compared to controls, with the mean average of $\mathrm{BC}$ for cases 4350 $\mu \mathrm{g} / \mathrm{m} 3$ and controls $4126 \mu \mathrm{g} / \mathrm{m3}$. In this study, BC is positively associated with a pneumonia episode. We also report the importance of unmodifiable and behaviourally modifiable factors on pneumonia episode in children.

Discussion: In conclusion, we show that children present during cooking, number of available windows and MUAC increased the likelihood of a pneumonia episode. We recommend household level behaviour changes and targeted IMCl including early effective detection and treatment of childhood pneumonia particularly in high pollution areas in Nigeria.

\section{Introduction}

Pneumonia is an inflammatory lung disease characterised by the build-up of fluid in the alveolus leading to obstructed breathing (Walker et al., 2013; CDC., 2016)\{Walker, 2013 \#22789;Walker, 2013 \#22789\}. It is caused predominantly, but not solely by bacteria, viruses and fungi and is one of the most serious forms of acute lower respiratory infection (ALRI). (Walker et al., 2013; CDC., 2016). Pneumonia is the leading cause of 
preventable paediatric deaths (especially in children under five) and associated morbidity globally (Walker et al., 2013; McCollum et al., 2015; UNICEF, 2016). In children, bacterial pneumonia is mostly caused by Streptococcus pneumoniae followed by Haemophilus influenzae type b (Hib) globally (Walker et al., 2013; CDC., 2016). More than 800,000 children under the age of five die every year from pneumonia (UNICEF, 2019). In Nigeria $19 \%$ of child deaths were due to pneumonia in 2018 , and it was a major killer of children under-five in 2017 (Estimation, 2019; IGME), 2019). A UNICEF report has shown that one in six children would develop pneumonia at least once before the age of ten particularly in the poorest parts of low and middle-income countries (UNICEF, 2016). Developing countries are also characterised by reduced access to quality health care, nutrition, and basic environmental hygiene which contributes to aggravating the disease incidence (UNICEF, 2016).

Indoor air pollution has been linked with increased risk of pneumonia particularly in children (Smith et al., 2000; Bruce et al., 2013; Ranabhat et al., 2015). Upon evasion by foreign organisms, the innate immune system mobilises specialised cells to digest and neutralise these, however exposure to high levels of pollutants has been shown to perturb this filtration mechanism thereby increasing the susceptibility to infections (Smith et al., 2000; Hussey et al., 2017). The immune system is thought to be weakest in the very young and in the aged thereby putting this age groups at increased risk of suffering adverse effects from any additional compromise to the immune system (Simon et al., 2015). Furthermore, Children have an increased oxygen requirement relative to their size, as well as narrower airways compared to adults. Thus, whilst a pollutant may cause a mild irritation in the adult airways, it can potentially result in a more significant obstruction in the airways of a young child (Bruce et al., 2013).

Particulate matter (PM) is the broad name used to characterise most types of pollutants (Smith et al., 2000). Inflammation and compromised immune defences that is linked to the development of ALRIs has been associated with exposure to PM (Smith et al., 2000). Particulate matter refers to a mixture of solid and liquid particles suspended in air which can be visible or invisible (Estimation, 2019). PM exists in different sizes usually denoted in $\mu \mathrm{m}$, from $\mathrm{PM}_{10}$ to $\mathrm{PM}_{1}$ (Massey et al., 2012; Estimation, 2019). Accumulating evidence shows that $\mathrm{PM}_{2.5}$ is dangerous to human health as it is able to penetrate nostril cilia and travel to the lungs where it can cause damage (Zajusz-Zubek et al., 2017). Particulate matter do not only differ in size but it also differs in composition depending on season and location (Massey et al., 2012; Carter et al., 2016; Estimation, 2019).

Limited studies assess the composition and effect of $\mathrm{PM}_{2.5}$ in Nigeria on pneumonia in children. More generally, whilst the effect of $\mathrm{PM}_{2.5}$ on health outcomes is usually been well researched globally, there is limited research on $\mathrm{PM}_{1}$ (Zajusz-Zubek et al., 2017). $\mathrm{PM}_{1}$ is the smallest detectable fraction of $\mathrm{PM}$ is possibly the most dangerous in children as it can easily by-pass air filtration systems and travel through nostrils, into lungs and blood vessels blood streams and by-pass air-filtration systems (Zajusz-Zubek et al., 2017). Exposure to $P M_{1}$, mostly outdoors have been linked to health outcome ranging from metabolic disorders, cancers, respiratory health disorders across health groups (Agudelo-Castañeda et al., 2017; Zajusz-Zubek et al., 2017; Yang et al., 2018). The link of $\mathrm{PM}_{1}$ to childhood pneumonia remains largely unexplored. 
Black carbon (BC), a known constituent of PM is increasingly gaining recognition as a mediator of adverse health outcomes (Smith et al., 2000). BC has been reported to facilitate the resistance of S. pneumonia to antibiotics by inducing a structural modification in the bacterial and promote the infectivity of the bacteria in the host cells (Baumgartner et al., 2014; Hussey et al., 2017). Nonetheless, the role of BC on respiratory disease incidence remains largely unexplored.

Most of the research carried out in low and middle-income countries has focused mainly on the risk factors associated with childhood pneumonia (Hulin et al., 2010; Mustapha et al., 2011). These studies might be limited because they depend on self-reported questionnaires on exposures, hence subject to several biases. The use of a specific instrument to quantify indoor air quality has enabled researchers to identify pollutants involved in causing diseases in rural and urban areas in France (Hulin et al., 2010) and in developing countries such as Eastern Indonesia (Shibata et al., 2014).

Several reviews have been published looking at the effect of indoor air pollution on pneumonia in children. However, there was no standard assessment for exposure across studies (Smith et al., 2000; Dherani et al., 2008; Rudan et al., 2008; Bruce et al., 2013; Jackson et al., 2013; Zar \& Ferkol, 2014; Buchner \& Rehfuess, 2015; Sonego et al., 2015). Also, the combination of varying study designs, sample sizes, follow up period and dose response renders the conclusions less useful and hard to interpret (Smith et al., 2000; Dherani et al., 2008; Rudan et al., 2008; Bruce et al., 2013; Jackson et al., 2013; Zar \& Ferkol, 2014; Buchner \& Rehfuess, 2015; Sonego et al., 2015). Finally, there was no consensus on what variables should be adjusted for across all reviews (Smith et al., 2000; Dherani et al., 2008; Rudan et al., 2008; Bruce et al., 2013; Jackson et al., 2013; Zar \& Ferkol, 2014; Buchner \& Rehfuess, 2015; Sonego et al., 2015). Indoor concentrations of carbon monoxide (CO), particulate matter (PM), or more recently volatile organic compounds (VOC) and black carbon (BC) concentrations have been associated with respiratory infections in children (Berglund $M, 1993$; Rumchev et al., 2004; Jung et al., 2012; Shibata et al., 2014). Unfortunately, the current understanding of the association of indoor air pollution on pneumonia in children under five is inconclusive and only partially understood.

Air pollution research and guidelines have exclusively focused on $\mathrm{PM}_{2.5}$ (Baumgartner et al., 2014; Shibata et al., 2014), including those proposed by the World Health Organisation rather than the sources or components (Berglund M, 1993; Schwartz J, 2000; Rumchev et al., 2004). Increasingly, BC is been reported to cause more adverse health outcomes than $\mathrm{PM}_{2.5}$ (Baumgartner et al., 2014). Previous studies have separate assessments of these pollutants, none assessing these simultaneously.

This study therefore, expands and measures additional pollutants such as carbon monoxide (CO) and black carbon (BC). This is the first study investigating based on primary field observation the association between specific indoor air pollutants $\left(\mathrm{PM}_{1}, \mathrm{PM}_{2.5}, \mathrm{CO}\right.$ and Black Carbon) and a pneumonia episode in children under five in Abuja, Nigeria.

\section{Methods}

\section{Study design and participant recruitment}


This case-control study recruited cases from eleven general hospitals and seven primary healthcare centres (PHC) in Abuja. All PHCs had primary health workers (PHWs) that provided basic health services both precautionary and curative care for common illnesses such as diarrhoea, malaria and pneumonia.

\section{Diagnosis of pneumonia and recruitment of cases.}

Cases were identified either following presumptive diagnosis by healthcare workers or where possible, radiographic confirmation of pneumonia. Cases were referred to our study by medical professionals in the different facilities. And at the end of the month total numbers of cases was collated manually from ward registers.

\section{Diagnosis of pneumonia}

We included clinically suspected (using IMCI Guidelines) and radiologically confirmed cases of Pneumonia.

Cases recruited from general hospitals were diagnosed using chest radiographs (gold standard). Clinically suspected cases were identified as per Integrated Management of Childhood IIIness (IMCI) Guidelines. Nonsevere pneumonia was defined as the presence of cough or difficulty breathing and fast breathing $(60,50$, or 40 breaths per min or higher in those aged $<2$ months, $2-12$ months, and $1-5$ years, respectively) (Mortimer et al., 2017b). Severe IMCI pneumonia was defined additionally by chest in-drawing, stridor, or any general danger sign (inability to drink or breastfeed, vomiting, convulsions, lethargy, or unconsciousness) (Mortimer et al., 2017b). Cases identified from primary health care centres were diagnosed using IMCI guidelines.

The following sampling approach was employed to collect data from a sample representative of the entire population. Applying judgement sampling approach (B, 2010; J \& R, 2013), Abuja was selected as the study location. A random sampling approach (Tyrer \& Heyman, 2018), was used to identify 20 urban and 20 rural enumeration areas within the different council areas. Hospitals and primary healthcare centres from these areas were approached and pneumonia cases recruited into the study. Adopting systemic sampling (Tyrer \& Heyman, 2018) the addresses of cases recruited from the hospitals were used as the starting point and control houses were identified by knocking every $4^{\text {th }}$ household within the same street where cases lived. If study criteria were not met the process was repeated until a household that met all study eligibility criteria was located. All households with children aged 0-5 were selected and parents were invited to participate.

Control households with children having cough or difficulty breathing, age-specific tachypnea, and auscultatory evidence of crepitation were not included and referred to the hospital for pneumonia tests. For inclusion, they must have lived in Abuja for the last five years and parents must have not moved houses in the last five years. Also, a control must be living in the same areas as a case.

Parents of all children were asked for their informed consent for recruitment into the study. Caregivers for cases, were contacted within one week of identification at participating hospitals and measurements were made within two weeks of identification based on participant availability and consent. Control participants were contacted immediately after consent was obtained from matching cases and measurements were made within two weeks of identification. 


\section{Air quality measurements}

We measured concentrations of carbon monoxide (CO), fine particles $\left(\mathrm{PM}_{2.5}\right.$ and $\left.\mathrm{PM}_{1}\right)$, and black carbon (BC). Black carbon was measured and monitored using a cell phone based system developed by NEXLEAF ANALYTICS (CD et al., 2004; Belanger et al., 2006; Chowdhury Z ER et al., 2007; Ramanathan N et al., 2011a; Ramanathan N et al., 2011b; Semple et al., 2015; Pillarisetti et al., 2017). This involves an optical technique where a photograph of the filter is captured with a cell-phone or a camera and transmitted to a server where an algorithm compares the image (the colour of the filter) with a calibrated scale (CD et al., 2004; Belanger et al., 2006; Chowdhury Z ER et al., 2007; Ramanathan N et al., 2011a; Ramanathan N et al., 2011b; Semple et al., 2015; Pillarisetti et al., 2017). The BC load is estimated by measuring its reflectance in the red wavelength, based on the "blackness" of the photograph. $\mathrm{PM}_{1}$ concentrations were measured using a battery-operated SidePak Personal Aerosol Monitor AM510 (TSI Inc, MN, USA) fitted with a PM 1 impactor and set to a calibration factor of 0.30 . In accordance with manufacturer's instructions, SidePak devices were cleaned, the impactor re-greased, zero calibrated and the flow rate set at $1.7 \mathrm{l} / \mathrm{min}$ before each use. $\mathrm{PM}_{1}$ measurements were logged at one-minute intervals, with each one-minute data point being an average of 60 seconds of sample measurements. $\mathrm{PM}_{2.5}$ and $\mathrm{CO}$ was monitored and measured using PATS+ which is a small, portable datalogging device that measures real-time particle concentrations. Its specifications include lower particulate matter detection limit of 10 to $20 \mu \mathrm{g} / \mathrm{m}^{3}$ upper particulate matter detection limit is 30,000 to $50,0000 \mu \mathrm{g} / \mathrm{m}^{3}$. These techniques have been validated in laboratory and household-level applications (CD et al., 2004; Belanger et al., 2006; Chowdhury Z ER et al., 2007; Ramanathan N et al., 2011a; Ramanathan N et al., 2011b) (Figure I). Air quality measurements were made in the cooking environment.

Each set of sampling data was downloaded from their monitors using their manufacturer's software (i.e. Trakpro and Pica software's and NEXLEAF Analytics Black Carbon portal) and transferred to STATA 16 (alongside the unique household ID). Each of the data was measured in a minute-by-minute format, except for PATs+ where the pollutants had measurements second by second, but were then aggregated to minute by minute to compute measures.

Data was matched for control and cases to ensure the same hours were been considered when making comparisons between both groups. For matching, each case was matched to its own control (obtained in the same geographical area). At the stated time points (3 to $24 \mathrm{~h}$ ), both the case and control needed to possess $3 \mathrm{~h}, 15 \mathrm{~h}$ or $24 \mathrm{~h}$ measurements to be included in the corresponding analysis at the time point. Data with no matched sample time were discarded, reducing the amount of sampling minutes to compare from 150 cases and 140 controls in total to 112 cases and 112 controls having 3 hours, 112 cases and 112 controls having 10 hours, 112 cases and 112 controls having $15 \mathrm{~h}$ and 112 cases and 112 controls having $24 \mathrm{~h}$ measurements. For paired analyses, the percentage change of pollutant $\left(\mathrm{PM}_{1}, \mathrm{PM}_{2.5}\right.$ and $\left.\mathrm{CO}\right)$ concentrations was determined by comparing the mean and median levels overall and in each case and control household. Although data distributions were skewed towards zero, we present arithmetic mean figures throughout since these are used by the WHO to define their upper guidance limits. To compare differences in exposure to our measures of indoor pollution between cases and controls we used the Wilcoxon signed-rank test. This test has been used in similar studies of air quality measurements (Woolson, 2008; Wittkowski \& Song, 2010). 


\section{Household questionnaires}

Information on demographics, socioeconomic status, environmental, structural characteristics of the house and health information of participants was collected using a structured questionnaire. Information on the health status of the child requested from parents on history and issues relating to pneumonia and malnutrition were as defined by the WHO (Chance, 2001; Fund, 2009; UNICEF, 2016). Finally, mid-upper arm circumference (MUAC) measuring tapes were used to map the prevalence of undernutrition within the study population (Fund, 2009).

\section{Data management and analyses}

First, we compared cases and controls based on: age, sex, socioeconomic status, income, immunization, and MUAC, and used chi-square to assess statistical difference. Using chi-square to assess statistical difference, we compared cases and controls in terms of structural characteristics of the house (e.g. number of windows, type of building materials used and type of roofing material used etc.) and lifestyle factors affecting exposure to pollutants(e.g. time children spent in the cooking environment, fuel type) .

We compared cases and controls in terms of mean, range, median, IQR and the proportion of time the $\mathrm{PM}_{2.5}$, $\mathrm{PM}_{1}$ and $\mathrm{CO}$ concentration exceeded WHO 24-hour mean $\mathrm{PM}_{2.5}$ upper limit of $25 \mu \mathrm{g} / \mathrm{m}^{3}$ (WHO, 2017), based on continuous indoor monitoring of 3,15 and 24 hours each of the specific air pollutant. Finally, to illustrate the sampled PM $\mathrm{X} . \mathrm{X}$ and $\mathrm{BC}$ distribution between pneumonia cases and controls we graphically constructed box plots. All analyses were performed in STATA version $16^{\text {TM }}$ and the confidence level was set to $95 \%$ with $p$ values $<0.05$ considered to be significant.

Given the influence of seasonality on the burden of pneumonia, data were collected throughout a year (January 2018 - January 2019). (Oluleye A et al., 2010). Rainy season was designated from April to October 2018, whilst dry season from January to March 2018 and November 2018 to January 2019. As seasonality is important in changing both the composition and concentration of pollutants, we carried out a sub group analysis by season.

\section{Ethics and ethical considerations for study}

Prior to data collection, the protocol for the study was reviewed and approved by the University of Nottingham Medical School Ethics Committee (Reference number: 134 - 1710) and the National Health Research Ethics Committee of Nigeria (Reference number: NHREC/01/01/2007). All procedures performed in this study were in accordance with the ethical standards of institutional research committees and with the 1964 Helsinki declaration and its amendments (Carlson et al., 2004).

\section{Results}

The study population comprised of 290 children. 150 cases (aged 1-59 months) presenting to the study hospitals and PHCs and 140 controls who met all eligibility criteria. Of these 30 households that had measurements less than $3 \mathrm{~h}$ or more than $24 \mathrm{~h}$ were discarded with their matched household making 60 in total. Three households had equipment tampering were also discarded with its matched household making 
six in total. The remaining 112 cases and 112 controls had measures on pollutants that ranged between 3 hours and 24 hours and were included in the analyses. Hence, cases and controls were matched based on time of the day and total time of data observed in order to compute comparable means and medians per household consisting of the same times of the day and same total number of minutes. Table I (below) summarises the number of children $\mathrm{IMCl}$ or radiographically diagnosed with pneumonia.

Nearly $50 \%$ of the population of cases and controls aged between 25 - 59 months, there was no significant difference of age between cases and controls with a $p$-value $>0.05$, sex was uneven amongst cases and control, with more girls approximately $63 \%$ in the case population, compared with $53 \%$ of girls making up the control population (Table I).

Socio economic status was defined as the ownership of certain physical assets as described in study questionnaire. $50 \%$ of cases where within the lowest social group, whilst it was roughly $39 \%$ of the control group within the lowest social category. However, for the middle group $50 \%$ was from the control households and $38 \%$ were cases. There was no difference observed within the highest socio-economic group with roughly $11 \%$ for both cases and controls.

There was a significant difference in undernutrition (MUAC) between cases and controls. Around, 62 (41\%) of case population were malnourished, compared to $32(23 \%)$ of the control population (Table I).

More cases $113(75 \%)$ were present in the cooking environment with their mothers during cooking, compared to $52(37 \%)$ being present in the control population. This difference was significant with a $P$-value $<0.05$ (Table II).

Within the households of cases approximately $43(29 \%)$ used liquid petroleum gas (LPG) compared to 31 $(22 \%)$ of controls. Similarly, $18(12 \%)$ of cases used kerosene compared to $28(20 \%)$ controls. However, it was clear that both cases $41(28 \%)$ and controls $36(26 \%)$ used a mixture of fuels for their daily needs.

In cases with lack of electricity, rechargeable electric lamps were the most common alternative source of lighting among study household with $52 \%$ cases and $61 \%$ controls. The second most common source of alternative lighting was generators with $29(20 \%)$ cases and 14 (10\%) controls using them (Table II).

Over, 105 controls had windows in their kitchens compared to 87 in cases with over 50 (36\%) cases reporting no windows in their kitchen (Table II).

\section{Estimated burden of pneumonia across medical facilities}

Table III summarises the estimated burden of pneumonia in children under- five who presented to the Hospitals and PHCs assessed over the 12-month study period. The overall highest and lowest estimated burden of pneumonia during the 12-month study period was $14.6 \%$ in October and $2.5 \%$ in January according to combined $\mathrm{IMCl}$ and radiographic diagnosis.

The estimated burden of pneumonia varied significantly across the study location and their respective hospital and PHCs. All healthcare facilities contributed at least one case during the study period. 
Across the board, mean $\mathrm{PM}_{2.5}$ was higher in controls compared to cases (Table IV). The highest mean recorded for controls was $177 \mu \mathrm{g} / \mathrm{m}^{3}$. However, there was a statistically significant difference in mean between cases $\left(129.3 \mu \mathrm{g} / \mathrm{m}^{3}\right)$ and controls $\left(176.97 \mu \mathrm{g} / \mathrm{m}^{3}\right)$ for 10 hour measures ( $P$-value 0.0147$)$, cases $\left(100.2 \mu \mathrm{g} / \mathrm{m}^{3}\right)$ and controls $\left(162.3 \mu \mathrm{g} / \mathrm{m}^{3}\right)$ for 15 hour measures ( $P$-value 0.0111$)$ and cases $\left(117.4 \mu \mathrm{g} / \mathrm{m}^{3}\right)$ and controls $\left(174.4 \mu \mathrm{g} / \mathrm{m}^{3}\right)$ for $20-24$ hour measures ( $P$-value 0.0296$)$ (Table IV).

$\mathrm{PM}_{2.5}$ was higher in rainy season than dry season by $11.7 \%$ at $3 \mathrm{~h}, 52.7 \%$ higher at $10 \mathrm{~h}, 44.4 \%$ higher at $15 \mathrm{~h}$ and $48.7 \%$ higher at $20-24 \mathrm{~h}$ for controls. In cases, $\mathrm{PM}_{2.5}$ was higher in rainy season than dry season by $11.9 \%$ at $3 \mathrm{~h}, 57 \%$ higher at $10 \mathrm{~h}, 45.9 \%$ higher at $15 \mathrm{~h}$ and $52.5 \%$ higher at $20-24 \mathrm{~h}$. Overall, $\mathrm{PM}_{2.5}$ was higher in cases during the rainy season than controls by $0.15 \%$ at $3 \mathrm{~h}, 5 \%$ higher at $10 \mathrm{~h}, 2 \%$ higher at $15 \mathrm{~h}$ and $4 \%$ higher/lower at 20-24h (Table V).

$\mathrm{PM}_{1}$ was higher in dry season than rainy season by $10.5 \%$ at $3 \mathrm{~h}, 16.5 \%$ higher at $10 \mathrm{~h}, 16.5 \%$ higher at $15 \mathrm{~h}$ and $12.5 \%$ higher at $20-24 \mathrm{~h}$ for controls. In cases, $\mathrm{PM}_{1}$ was higher in dry season than rainy season by $5.4 \%$ at $3 \mathrm{~h}$, but $\mathrm{PM}_{1}$ was higher in rainy season than dry season by $4.9 \%$ higher at $10 \mathrm{~h}, 6.8 \%$ higher at $15 \mathrm{~h}$ and 9.4\% higher at $20-24 \mathrm{~h}$. Overall, $\mathrm{PM}_{1}$ was higher in cases during the rainy season than controls by $4 \%$ at $3 \mathrm{~h}$, $21.6 \%$ higher at $10 \mathrm{~h}, 24.4 \%$ higher at $15 \mathrm{~h}$ and $21.3 \%$ higher/lower at $20-24 \mathrm{~h}$ (Table V). There was no significant difference in exposure to $\mathrm{PM}_{1}$ between cases and controls with $\mathrm{PM}_{1}$ consistently higher in controls compared to cases. With the highest $\mathrm{PM}_{1}$ mean concentration recorded being $124 \mu \mathrm{g} / \mathrm{m}^{3}$ (Table V)

\section{BC}

There was a significant difference ( $p$-value 0.0260 ) in exposure to Black Carbon between cases and controls. With the average mean for cases $4350 \mu \mathrm{g} / \mathrm{m}^{3}$ and controls $4126 \mu \mathrm{g} / \mathrm{m}^{3}$.

In all the cases identified in the study, $24.11 \%$ of measurements were from IMCI diagnosed Pneumonia and $75.89 \%$ were from pneumonia confirmed by chest radiographs in hospital. BC was higher in rainy season than dry season by $13 \%$ at $20-24 \mathrm{~h}$. In cases, BC was higher in rainy season than dry season by $10.80 \%$ at $20-$ 24h (Table V).

\section{CO}

For controls CO was higher in rainy season than dry season by $41.9 \%$ at $3 \mathrm{~h}, 30.6 \%$ higher at $10 \mathrm{~h}, 36 \%$ higher at $15 \mathrm{~h}$ and $43.7 \%$ higher at $20-24 \mathrm{~h}$. In cases, $\mathrm{CO}$ was higher in rainy season than dry season by $54.4 \%$ at $3 \mathrm{~h}$, $34.8 \%$ higher at $10 \mathrm{~h}, 42 \%$ higher at $15 \mathrm{~h}$ and $46.6 \%$ higher at $20-24 \mathrm{~h}$. Overall, $\mathrm{CO}$ was higher in cases during the rainy season than controls by $27 \%$ at $3 \mathrm{~h}, 5.5 \%$ higher at $10 \mathrm{~h}, 9 \%$ higher at $15 \mathrm{~h}$ and $4 \%$ higher/lower at 20 $24 \mathrm{~h}$ (Table V). There was no significant difference in $\mathrm{CO}$ concentration between cases and controls. With the highest CO mean concentration recorded being $2930 \mu \mathrm{g} / \mathrm{m}^{3}$.

Over all, concentrations of pollutants were higher during the rainy season compared to dry season. The highest reported mean concentration $(289.62 \mu \mathrm{g} / \mathrm{m} 3)$ was observed when cases and controls where 
compared after a 10-hour period. Overall concentrations of $\mathrm{PM}_{1}$ were higher in most cases during the dry season.

Distribution of $\mathrm{PM}_{2.5}$ and $\mathrm{BC}$ concentrations was measured between houses of cases and controls. When outside (Figure II) values were excluded $\mathrm{PM}_{2.5}$ was higher in controls during the dry season compared to cases, with the highest mean value over $150 \mu \mathrm{g} / \mathrm{m}^{3}$. However, in contrast BC was higher in cases compared to controls both during the rainy and dry season, the highest mean of over $11,000 \mu \mathrm{g} / \mathrm{m}^{3}$.

\section{Discussion}

\section{Effect of indoor air pollutants and pneumonia incidence}

This is the first study to measure and compare the association between indoor air quality in terms of specific component pollutants $\left(\mathrm{PM}_{2.5}, \mathrm{PM}_{1}, \mathrm{CO}\right.$ and $\left.\mathrm{BC}\right)$ and pneumonia episodes in children under five in Abuja, Nigeria. Previous studies have measured single pollutants or used proxies measurements in the absence of observed primary data (Broor et al., 2001; Mahalanabis et al., 2002; Dherani et al., 2008; Bassani et al., 2010; Dhimal et al., 2010; Dionisio et al., 2012; Bruce et al., 2013; Jackson et al., 2013; Karki et al., 2014; Ram et al., 2014; Shibata et al., 2014; Zar \& Ferkol, 2014; Buchner \& Rehfuess, 2015; Kelly et al., 2015; Sonego et al., 2015; Howie et al., 2016; PrayGod et al., 2016; Mortimer et al., 2017a). We have previously reported that when directly measuring pollutants, there was no association with pneumonia incidence, but when using biomass fuel as a proxy, there was (Adaji EE et al., 2019). This highlights the need for targeted approaches for measuring indoor pollutant levels. Studies directly measuring BC levels in association with pneumonia incidence are scarce. Herein, we also report the importance of behaviourally modifiable and unmodifiable factors during the study period on pneumonia incidence in children. Unmodifiable factors include increasing the number of windows and doors in the kitchen and the entire house whilst behaviourally modifiable factors, such as behavioural changes that might arise from consultation with healthcare professionals like, cooking with cleaner fuels, keeping children away from the cooking environment and opening windows more to allow the flow of fresh air.

In this study, we found that most participants were exposed to levels of pollution that overwhelmingly exceed WHO guidelines. Whilst it might be expected to find higher levels of household air pollution in households where there had been a reported case of childhood pneumonia, we found that both cases and controls were exposed to extreme levels of household air pollution. In some cases the levels were 10 times higher than the WHO guidelines, which confirms published reports from the WHO reporting extreme levels of exposure (Bank, 2015; WHO, 2016a). For individual pollutants, we found that the mean $\mathrm{PM}_{2.5}$ was higher in controls compared to cases (Table IV). There was no significant difference in $\mathrm{CO}$ concentration between cases and controls. There was no significant difference in $\mathrm{PM}_{1}$ between cases and controls ( $P$-value $\left.>0.05\right)$. Furthermore, there was a significant difference ( $P$-value 0.0260) in exposure to Black Carbon between cases and controls. BC was higher in households of cases compared to controls.

The finding that $\mathrm{PM}_{2.5}$ was higher in controls than cases was initially perplexing, however, it is important to note that the study design was such that measurements were made following a lag time from when cases

Page 10/38 
presented to hospital and consent was given to take measurements. The presence of a sick child and visit to health care centres presents the possibilities of behavioural changes following medical advice (Institute of Medicine (US) Committee on Health and Behavior: Research, 2001). Education on pollution levels and practical actions to reducing indoor pollution such as opening of windows is part of the care given to parents and caregivers when treatment is sought (Institute of Medicine (US) Committee on Health and Behavior: Research). This can potentially lead to modifications in habits that could have led to reduction in $\mathrm{PM}_{2.5}$ levels prior to our measurements among cases. Future studies should adopt a study design that follows a representative sample within a prolonged timeframe where periodic indoor air quality measurements are observed and respiratory symptoms are continuously monitored by a healthcare professional to give a wholistic view of exposure to pollutants and pneumonia association. We return to the effect of unmodifiable factors later in this discussion.

Nonetheless, there was higher $\mathrm{BC}$ measures in houses with a pneumonia episode. Furthermore, within matched time frames, the average BC load was higher in cases compared to controls (Figure II). This result is in line with results from in vitro studies conducted by Hussey et al (Hussey et al., 2017) that reported BC promotes infectivity of $S$. pneumoniae in host cells and facilitates its resistance to multiple antibiotics (Baumgartner et al., 2014; Hussey et al., 2017).

In recent times, there has been increased interest into the role of black carbon in climate change, air quality and health (Bond et al., 2013). Epidemiological studies have shown that BC is a better indicator for shortterm health effects compared to undifferentiated PM mass (WHO, 2016b). Furthermore, pneumococcal bacteria which causes pneumonia has been shown to be more associated with $B C$ than with $\mathrm{PM}_{2.5}$ (Shears et al., 2020), suggesting that $B C$ is a better indicator of harmful particulate substances from combustion sources than undifferentiated PM mass. Whilst $\mathrm{PM}_{2.5}$ has been widely used in the literature as an indicator of indoor air pollution (Nicole AH Janssen et al., 2012; Zajusz-Zubek et al., 2017), new research is showing that it in itself contains $\mathrm{PM}_{1}$ and $\mathrm{BC}$ in different proportions depending on the source (Nicole $\mathrm{AH}$ Janssen et al., 2012; Zajusz-Zubek et al., 2017). This finding highlights the importance to measure each pollutant and not depend on proxies or surrogate markers of the pollutants. This is therefore the first case-control study to investigate and report an association between BC and childhood pneumonia at the household level in Abuja, Nigeria. Furthermore, this is the first population-based study to report this association; previous studies investigating the influence of $\mathrm{BC}$ have been done mostly in controlled settings.

There was an association of seasonality on pollutant levels. We found that households were exposed to higher concentration of $\mathrm{PM}_{2.5}, \mathrm{CO}$ and $\mathrm{BC}$ during rainy season compared to dry season, this could be due to increased cooking activities indoors during the rainy season. This reinforces previous findings where higher exposure during the rainy season compared to the dry season has been observed in other studies (Massey et al., 2012; Carter et al., 2016; Ni et al., 2016). However, $\mathrm{PM}_{1}$ was higher during the dry (i.e. November to March) season compared to rainy season (i.e. April to October). This could be due to increased exposure to outdoor air whilst cooking outside during dry seasons (Zhang et al., 2007).

Seasonality is important in changing both the composition and concentration of pollutants. For example, in a study conducted in Italy, $\mathrm{PM}_{2.5}$ analysed in the winter months was made up of organic species and 
products of combustion such as from heating however, in the spring and summer months, the same $\mathrm{PM}_{2.5}$ was characterised by soil-related organic components and secondary inorganic components (Tofful \& Perrino, 2015). As lifestyle is significantly affected by season it is not inconceivable that the compositions of PM between seasons in Nigeria is likely to also vary and requires careful evaluation. However, it is important to note that a longer study of at least two years is required to fully understand the effect of seasonality on pollutants and disease incidence.

\section{Malnutrition and pneumonia incidence}

Furthermore, our results indicate that cases were more likely to be undernourished ( $p$-value $<0.05$ ). This result agrees with existing research; most healthy children can fight the infection with their natural defences, children whose immune systems are compromised are at higher risk of developing pneumonia, although it is difficult to ascertain if malnutrition in this case, was present before pneumonia episode or was a consequence of the disease. A child's immune system may be weakened by malnutrition especially in infants who are not exclusively breastfed (Thörn et al., 2011; WHO, 2019). Childhood undernutrition, especially wasting (children who have a weight too low for their height) is a risk factor for pneumonia in children (Troeger et al., 2018). It contributed to 53\% of pneumonia deaths in 2017 in children under five in Nigeria. Without sufficient energy intake the body cannot cope with increased energy demands required to fight off the infection. A literature review of pneumonia in malnourished children by Chisti and colleagues found that undernourished children are between two and four times more likely to be admitted to hospital due to pneumonia and up to 15 times more likely to die from it in developing countries (Chisti et al., 2009).

\section{Effect of behaviourally modifiable and unmodifiable factors.}

As previously mentioned, behaviourally modifiable factors may have affected our observations and interpretation of the pneumonia episodes. The problem is that results could have been different if behaviour has been affected after the hospital/health care advice.

Alongside pollution levels, a higher proportion of cases were within the lowest socioeconomic group compared to controls. Poverty is known to affect early treatment seeking behavior by care givers predominantly due to barriers to financial access (Alegana et al., 2017). Treatment seeking behavior is associated with high disease incidence usually in low-income countries (Alegana et al., 2017).

In general, we found that more cases $(75 \%)$ were present in the cooking environment accompanying their mothers during cooking, compared to $37 \%$ of the control group. A study assessing cooking fuel choice in Lagos, Nigeria, reports the choice of cooking fuels was predominantly kerosene, followed by charcoal and liquified petroleum gas was the least used (Ozoh et al., 2018). Dirty cooking fuels such as kerosene and firewood are known to increase household pollution levels increasing the risk of health damaging effects (Ozoh et al., 2018). In this study, $12 \%$ of cases used kerosene compared to $20 \%$ of controls. Furthermore, $12 \%$ of cases used biomass fuel while $11.5 \%$ of control. Overall, a high percentage of the study population used a combination of these fuel choices. This therefore suggests, time children spent with their mothers during cooking is an important factor to consider in reducing pollution-induced pneumonia incidence. Time 
spent in cooking-environment is a behaviourally modifiable factor, which following education to care-givers can have beneficial effects on pneumonia incidence.

Interestingly, we noted that, of the cases present with mothers during cooking, $63 \%$ of them were females compared to $37 \%$ males. This gender difference was also significant with a $p$-value $<0.05$. This is consistent with the literature that women and children, especially female children are often with their parents during cooking (Clougherty, 2010; Dong et al., 2011; Dutta \& Banerjee, 2014; Devakumar et al., 2018). This gender bias means that women and female children are more frequently exposed to the dangers of indoor air pollution (Clougherty, 2010; Dong et al., 2011; Dutta \& Banerjee, 2014; Devakumar et al., 2018). This can be due to the observation that culturally women are responsible for cooking, cleaning and childcare which could contribute to this observation. Although sex is a unmodifiable construct in this setting, both genders could respond differently to the exposure to pollutants hence the observed differences (Clougherty, 2010). Therefore, more research is required to fully understand why this observation occurs.

Bruce et al. found that windows did not have an independent association with indoor air pollution exposure of children. Contrary to Bruce et al.'s (Bruce et al., 2004a) findings, we found that cases had lower number of windows in the kitchen which suggests that there can be an association between less ventilation, $\mathrm{BC}$ levels and a pneumonia episode. Our finding that number of windows and ventilation holes have a positive association with the likelihood of a recent pneumonia episode in children under five may not only be due to differences in size of these structures, location, and frequency of keeping windows open as observed by Jing Chang et al (Chang et al., 2018). It is likely that in some households, though there is an active chimney, owing to poor house construction (lack of concrete material), smoke removed from the chimney may be circulating back into the house owing to porous walls. Echoing Langbien's (Langbein, 2017) finding which suggests the need to study pollutant exposure and its impact on human health under various ventilation conditions and cooking locations.

In summary, our observations showed that unmodifiable factors such as reduced number of windows showed a statistically significant difference between those who had a pneumonia episode and those who didn't, whereas behaviorally modifiable factors such as opening of windows could potentially have a positive effect on reducing pollution levels but not enough to reach WHO "safe" levels.

\section{Strengths and limitations of the current study}

We employed a case control study design to compare exposures to different indoor pollutants between cases and controls with the assumption that they would have similar exposures. However, a limitation to this approach was that cases where recruited from hospitals, which might influence the post diagnosed exposure of the child.

Measurements were taken over 24 hours. In 60 households equipment was tampered with (e.g. by blocking the air inlet or batteries running out due to electricity issues) or experienced interruption in device power supply leading to a break in the continuous measurements over the $24 \mathrm{~h}$ period. Second, we also had measures for less than 24 hours while WHO guidelines are based on 24 hour measures. 
We cannot rule out selection bias within the cases population as only a certain group of people choose to go and can afford to go to the hospital.

A major strength of this study is that it measures for the first time the association of multiple component exposures of household air pollution $\left(\mathrm{PM}_{1} \mathrm{PM}_{2.5}, \mathrm{CO}\right.$ and $\left.\mathrm{BC}\right)$ and pneumonia in Abuja, Nigeria. This works strengthens available primary data evidence on the effects of indoor air pollution on pneumonia episodes in children under five.

\section{Recommendations from our findings}

The reduction of pneumonia incidence in children under five in Nigeria is urgently needed and this requires a multifaceted approach from the government, caregivers and other stakeholders. Educational and health promotion campaigns to prevent exposure of children under five to pollutants from cooking fuel is essential because the understanding the health consequences of indoor pollution amongst the studied population varies considerably. Certain people think it's the presence of smoke from burning biomass, making a kerosene stove cleaner, whilst others believe that any source of fuel other than electricity and LPG is polluting the indoor environment (Usman \& Sheu, 2010; Isara \& Aigbokhaode, 2014; Sadoh et al., 2015). Also, in Nigeria there is a lack of knowledge that links pollution to pneumonia amongst caregivers. When asked, most responders did not think smoke was a risk factor that could be linked with childhood pneumonia and accordingly did not think that avoiding smoke in their homes could prevent pneumonia in their children (Sadoh et al., 2015). Public health education of the public at large with routine reminders on the dangers of using solid fuels for cooking and potential health implications would be beneficial.

Furthermore, we propose active prevention actions such as cleaner fuel choices, household behavioural modifications such as reducing child presence in the cooking environment and encouraging the opening of windows for optimal ventilation (Chang et al., 2018). Firstly, it can thus be summarised that the lack of stable electricity, lack of access to affordable clean fuels and a lack of clear health benefits of using clean fuels have acted as primary obstacles to energy transition (Bruce et al., 2004b). The development of infrastructure to facilitate access to clean fuels and promotion of safety consciousness should be considered. Second, children should be kept away from cooking areas to help reduce their exposure to pollutants emitted during cooking. This is crucial because children in homes that uses good quality chimney stoves and exclusive use of gas cookers, still show high exposure levels (Bruce et al., 2004b). This information needs to be reiterated in schools, hospitals and through the media for parents to be well informed.

We also propose early and effective treatment seeking as beneficial to reducing pneumonia incidence. Early treatment is not common in Nigeria, most homes are at the lower socio economic class with little purchasing power. For these families, the first point of call are often pharmacies, which indirectly encourages home treatment and self-mediation (Elimian et al., 2020). We recommend any ongoing public health interventions aimed at mitigating the burden of pneumonia episodes in children under five nationally, should focus on improving the access to early detection and treatment, IMCl community training of healthcare workers at the local level and improvement of the standard of healthcare centres, as priority outcomes. 
Finally, a more targeted research approach and effective monitoring of the implementation of current and new policies is needed particularly in high population areas. One aspect of the problem so far is the lack of household air quality monitoring in Nigeria. This study provides a representation of the household air quality factors associated with pneumonia episodes in children under five in Nigeria. Therefore, results reported in this study can help guide the government and public health practitioners in developing appropriate household and treatment seeking behaviour interventions and a review of the policy around air quality and childhood respiratory illnesses in Nigeria.

\section{Conclusion}

In conclusion, we report, a statistically significant differences between BC levels and a pneumonia episode in a case-control study. We confirm that time spent in cooking environment was associated with a pneumonia episode. The number of windows in the house was positively associated with a pneumonia episode in children under five. We propose a multifaceted approach that combines educational and health promotion campaigns to prevent childhood pneumonia. This includes, promoting healthy housing and behaviour changes that support exposure reduction and adequate ventilation, early treatment seeking behaviour and targeted implementation of the Integrated Management of Childhood Illness particularly in high pollution areas is an important step in reducing the pneumonia burden in children under five in Nigeria.

\section{Declarations}

\section{Ethics approval and consent to participate}

Prior to data collection, the protocol for this study was reviewed and approved by the University of Nottingham Medical School Ethics Committee (Reference number: 134 - 1710) and the National Health research Ethics Committee of Nigeria (Reference number: NHREC/01/01/2007). And consent was sort from all study participants.

\section{Consent for publication}

Consent was sort from participants.

\section{Availability of data and materials}

The datasets during and/or analysed during the current study available from the corresponding author on reasonable request.

\section{Competing interests}

The authors declare that they have no competing interests

\section{Funding}

No external funding was obtained for this research 


\section{Authors' contributions}

EEA, JG, MC and RP conceptualized the study. EEA and MB analysed and interpreted the data regarding air quality measurements. All authors contributed for preparation of manuscript and all authors read and approved the final manuscript.

\section{Acknowledgements}

Not applicable

\section{References}

Adaji EE, Ekezie W, Clifford M, . PR (2019). Understanding the effect of indoor air pollution on pneumonia in children under 5 in low- and middle-income countries: a systematic review of evidence. Environmental science and pollution research international. 26: 3208-3225.

Agudelo-Castañeda DM, Teixeira EC, Schneider IL, Lara SR, Silva LFO (2017). Exposure to polycyclic aromatic hydrocarbons in atmospheric PM1.0 of urban environments: Carcinogenic and mutagenic respiratory health risk by age groups. Environmental Pollution 224: 158-170.

Alegana VA, Wright J, Pezzulo C, Tatem AJ, Atkinson PM (2017). Treatment-seeking behaviour in low- and middle-income countries estimated using a Bayesian model. BMC Med Res Methodol 17: 67-67.

B Z (2010). Focus Group. In: Social research methods. edn. Oxford University Press: Oxford.

Bank W (2015). A Plea for Action against Pollution in Nigeria.

Bassani DG, Jha P, Dhingra N, Kumar R (2010). Child mortality from solid-fuel use in India: A nationallyrepresentative case-control study. BMC Public Health 10: 279.

Baumgartner J, Zhang Y, Schauer JJ, Huang W, Wang Y, Ezzati M (2014). Highway proximity and black carbon from cookstoves as a risk factor for higher blood pressure in rural China. Proceedings of the National Academy of Sciences of the United States of America 111:13229-13234. 
Belanger K, Gent JF, Triche EW, Bracken MB, Leaderer BP (2006). Association of indoor nitrogen dioxide exposure with respiratory symptoms in children with asthma. American journal of respiratory and critical care medicine 173: 297-303.

Berglund M BC, Bylin G, Ewetz L, Gustafsson L, Moldeus P, et al (1993). HEALTH RISK-EVALUATION OF NITROGEN-OXIDES. SCANDINAVIAN JOURNAL OF WORK ENVIRONMENT \& HEALTH 19: 1-72.

Bond TC, Doherty SJ, Fahey DW, Forster PM, Berntsen T, DeAngelo BJ, Flanner MG, Ghan S, Kärcher B, Koch D, Kinne S, Kondo Y, Quinn PK, Sarofim MC, Schultz MG, Schulz M, Venkataraman C, Zhang H, Zhang S, Bellouin N, Guttikunda SK, Hopke PK, Jacobson MZ, Kaiser JW, Klimont Z, Lohmann U, Schwarz JP, Shindell D, Storelvmo T, Warren SG, Zender CS (2013). Bounding the role of black carbon in the climate system: A scientific assessment. Journal of Geophysical Research: Atmospheres 118: 5380-5552.

Broor S, Pandey RM, Ghosh M, Maitreyi RS, Lodha R, Singhal T, Kabra SK (2001). Risk factors for severe acute lower respiratory tract infection in under-five children. Indian pediatrics 38: 1361-1369.

Bruce N, McCracken J, Albalak R, Schei MA, Smith KR, Lopez V, West C (2004a). Impact of improved stoves, house construction and child location on levels of indoor air pollution exposure in young Guatemalan children. Journal of exposure analysis and environmental epidemiology 14 Suppl 1: S26-33.

Bruce N, McCracken J, Albalak R, Scheid M, Smith KR, Lopez V, West C (2004b). Impact of improved stoves, house construction and child location on levels of indoor air pollution exposure in young Guatemalan children. Journal of Exposure Science \& Environmental Epidemiology 14: S26-S33.

Bruce NG, Dherani MK, Das JK, Balakrishnan K, Adair-Rohani H, Bhutta ZA, Pope D (2013). Control of household air pollution for child survival: Estimates for intervention impacts. BMC Public Health 13 Suppl 3: S8.

Buchner $\mathrm{H}$, Rehfuess EA (2015). Cooking and season as risk factors for acute lower respiratory infections in African children: a cross-sectional multi-country analysis. PloS one 10: e0128933. 
Carlson RV, Boyd KM, Webb DJ (2004). The revision of the Declaration of Helsinki: past, present and future. Br J Clin Pharmacol 57: 695-713.

Carter E, Archer-Nicholls S, Ni K, Lai AM, Niu H, Secrest MH, Sauer SM, Schauer JJ, Ezzati M, Wiedinmyer C, Yang X, Baumgartner J (2016). Seasonal and Diurnal Air Pollution from Residential Cooking and Space Heating in the Eastern Tibetan Plateau. Environmental Science \& Technology 50: 8353-8361.

CD L, SK, Edwards R, T A (2004). Combined optical and ionization measurement techniques for inexpensive characterization of micrometer and submicrometer aerosols. Aerosol Science and Technology 38: 10541062.

CDC. (2016). Help Prevent Pneumonia [Internet]. Centers for Disease Control and Prevention. .

Chance GW (2001). Environmental contaminants and children's health: Cause for concern, time for action. Paediatrics \& Child Health 6: 731-743.

Chang J, Liu W, Huang C (2018). Residential Ambient Traffic in Relation to Childhood Pneumonia among Urban Children in Shandong, China: A Cross-Sectional Study. International journal of environmental research and public health 15: 1076.

Chisti MJ, Tebruegge M, La Vincente S, Graham SM, Duke T (2009). Pneumonia in severely malnourished children in developing countries - mortality risk, aetiology and validity of WHO clinical signs: a systematic review. Tropical medicine \& international health : TM \& IH 14: 1173-1189.

Chowdhury Z ER, Johnson M, Shields KN, Allen T, Canuz E, KR S (2007). An inexpensive light-scattering particle monitor: chamber and field validations with woodsmoke. Journal of Environmental Monitoring 9: 1099-1106.

Clougherty JE (2010). A growing role for gender analysis in air pollution epidemiology. Environmental health perspectives 118: 167-176. 
Devakumar D, Qureshi Z, Mannell J, Baruwal M, Sharma N, Rehfuess E, Saville NM, Manandhar DS, Osrin D (2018). Women's Ideas about the Health Effects of Household Air Pollution, Developed through Focus Group Discussions and Artwork in Southern Nepal. International journal of environmental research and public health 15: 248.

Dherani M, Pope D, Mascarenhas M, Smith KR, Weber M, Bruce N (2008). Indoor air pollution from unprocessed solid fuel use and pneumonia risk in children aged under five years: a systematic review and meta-analysis. Bulletin of the World Health Organization 86: 390-398C.

Dhimal M, Dhakal P, Shrestha N, Baral K, Maskey M (2010). Environmental burden of acute respiratory infection and pneumonia due to indoor smoke in Dhading. Journal of Nepal Health Research Council 8: 1-4.

Dionisio KL, Howie SR, Dominici F, Fornace KM, Spengler JD, Donkor S, Chimah O, Oluwalana C, Ideh RC, Ebruke B, Adegbola RA, Ezzati M (2012). The exposure of infants and children to carbon monoxide from biomass fuels in The Gambia: a measurement and modeling study. J Expo Sci Environ Epidemio/ 22: 173181.

Dong G-H, Chen T, Liu M-M, Wang D, Ma Y-N, Ren W-H, Lee YL, Zhao Y-D, He Q-C (2011). Gender differences and effect of air pollution on asthma in children with and without allergic predisposition: northeast Chinese children health study. PloS one 6: e22470-e22470.

Dutta S, Banerjee S (2014). Exposure to Indoor Air Pollution \& Women Health: The Situation in Urban India. Environment and Urbanization ASIA 5: 131-145.

Elimian KO, Myles PR, Phalkey R, Sadoh A, Pritchard C (2020). 'Everybody in Nigeria is a doctor...: a qualitative study of stakeholder perspectives on lay diagnosis of malaria and pneumonia in Nigeria. Journal of public health (Oxford, England) 42: 353-361.

Emenius G, Svartengren M, Korsgaard J, Nordvall L, Pershagen G, Wickman M (2004). Building characteristics, indoor air quality and recurrent wheezing in very young children (BAMSE). Indoor air 14: 34- 
Estimation UNI-AGfCM (2019). Save the Children's Child Inequality Tracker; MICS 2016 -2017; Mortality rates are calculated for the 10-year-period preceding the DHS survey; Nigeria Demographic and Health Survey 2018

Fund WHOatUNCs (2009). WHO child growth standards and the identification of severe acute malnutrition in infants and children A Joint Statement by the World Health Organization and the United Nations Children's Fund

Howie SRC, Schellenberg J, Chimah O, Ideh RC, Ebruke BE, Oluwalana C, Mackenzie G, Jallow M, Njie M, Donkor S, Dionisio KL, Goldberg G, Fornace K, Bottomley C, Hill PC, Grant CC, Corrah T, Prentice AM, Ezzati M, Greenwood BM, Smith PG, Adegbola RA, Mulholland K (2016). Childhood pneumonia and crowding, bedsharing and nutrition: A case-control study from The Gambia. The International Journal of Tuberculosis and Lung Disease 20: 1405-1415.

Hulin M, Caillaud D, Annesi-Maesano I (2010). Indoor air pollution and childhood asthma: Variations between urban and rural areas. Indoor air 20: 502-514.

Hussey SJK, Purves J, Allcock N, Fernandes VE, Monks PS, Ketley JM, Andrew PW, Morrissey JA (2017). Air pollution alters Staphylococcus aureus and Streptococcus pneumoniae biofilms, antibiotic tolerance and colonisation. Environ Microbiol 19: 1868-1880.

IGME) UNI-aGfCMEU (2019). Levels \& Trends in Child Mortality: Report 2019, Estimates developed by the United Nations Inter-agency Group for Child Mortality Estimation. New York: United Nations Children's Fund

Institute of Medicine (US) Committee on Health and Behavior: Research P, and Policy (2001). Health and Behavior: The Interplay of Biological, Behavioral, and Societal Influences. edn, vol. 5. Washington (DC): National Academies Press (US): Washington (DC). 
Institute of Medicine (US) Committee on Health and Behavior: Research P, and Policy. Individuals and Families: Models and Interventions. In. Health and Behavior: The Interplay of Biological, Behavioral, and Societal Influences. Vol. 5. Washington (DC): National Academies Press (US).

Isara AR, Aigbokhaode AQ (2014). Household Cooking Fuel Use among Residents of a Sub-Urban Community in Nigeria: Implications for Indoor Air Pollution. Eurasian J Med 46: 203-208.

J R, R O (2013). Qualitative research practice: a guide for social science students and researchers. edn. Sage Publications: London.

Jackson S, Mathews KH, Pulanic D, Falconer R, Rudan I, Campbell H, Nair H (2013). Risk factors for severe acute lower respiratory infections in children: a systematic review and meta-analysis. Croat Med J 54: 110121.

Jung KH, Hsu S-I, Yan B, Moors K, Chillrud SN, Ross J, Wang S, Perzanowski MS, Kinney PL, Whyatt RM, Perera FP, Miller RL (2012). Childhood exposure to fine particulate matter and black carbon and the development of new wheeze between ages 5 and 7 in an urban prospective cohort. Environment international 45: 44-50.

Karki S, Fitzpatrick AL, Shrestha S (2014). Risk Factors for Pneumonia in Children under 5 Years in a Teaching Hospital in Nepal. Kathmandu University medical journal (KUMJ) 12: 247-252.

Kelly MS, Wirth KE, Madrigano J, Feemster KA, Cunningham CK, Arscott-Mills T, Boiditswe S, Shah SS, Finalle $\mathrm{R}$, Steenhoff AP (2015). The effect of exposure to wood smoke on outcomes of childhood pneumonia in Botswana. The international journal of tuberculosis and lung disease : the official journal of the International Union against Tuberculosis and Lung Disease 19: 349-355.

Langbein J (2017). Firewood, smoke and respiratory diseases in developing countries-The neglected role of outdoor cooking. PloS one 12: e0178631. 
Mahalanabis D, Gupta S, Paul D, Gupta A, Lahiri M, Khaled MA (2002). Risk factors for pneumonia in infants and young children and the role of solid fuel for cooking: A case-control study. Epidemiology and infection 129: $65-71$.

Massey D, Kulshrestha A, Masih J, Taneja A (2012). Seasonal trends of PM10, PM5.0, PM2.5 \& PM1.0 in indoor and outdoor environments of residential homes located in North-Central India. Building and Environment 47: 223-231.

McCollum ED, King C, Hollowell R, Zhou J, Colbourn T, Nambiar B, Mukanga D, Burgess DCH (2015). Predictors of treatment failure for non-severe childhood pneumonia in developing countries - systematic literature review and expert survey - the first step towards a community focused mHealth risk-assessment tool? BMC Pediatrics 15: 547.

Mortimer K, Ndamala CB, Naunje AW, Malava J, Katundu C, Weston W, Havens D, Pope D, Bruce NG, Nyirenda M, Wang D (2017a). A cleaner burning biomass-fuelled cookstove intervention to prevent pneumonia in children under 5 years old in rural Malawi (the Cooking and Pneumonia Study): a cluster randomised controlled trial. The Lancet 389: 167-175.

Mortimer K, Ndamala CB, Naunje AW, Malava J, Katundu C, Weston W, Havens D, Pope D, Bruce NG, Nyirenda M, Wang D, Crampin A, Grigg J, Balmes J, Gordon SB (2017b). A cleaner burning biomass-fuelled cookstove intervention to prevent pneumonia in children under 5 years old in rural Malawi (the Cooking and Pneumonia Study): a cluster randomised controlled trial. The Lancet 389: 167-175.

Moya J BC, Etzel RA (2004). Children's Behavior and Physiology and How It Affects Exposure to Environmental Contaminants. Pediatrics 113: 996-1006.

Mustapha A, Briggs D, Hansell A (2011). Burden of Childhood Respiratory Illness and Indoor Air Pollution in the Niger Delta, Southern Nigeria. Epidemiology 22: S151.

Ni K, Carter E, Schauer JJ, Ezzati M, Zhang Y, Niu H, Lai AM, Shan M, Wang Y, Yang X, Baumgartner J (2016). Seasonal variation in outdoor, indoor, and personal air pollution exposures of women using wood stoves in 
the Tibetan Plateau: Baseline assessment for an energy intervention study. Environment International 94: 449-457.

Nicole AH Janssen, Miriam E Gerlofs-Nijland, Timo Lanki, Raimo O Salonen, Flemming Cassee, Gerard Hoek, Paul Fischer, Bert Brunekreef, Krzyzanowski M (2012). Health effects of black carbon. World Health Organization Regional Office for Europe.

Oluleye A, Akinbobola A, Oluleye A, A. A (2010). Malaria and pneumonia occurrence in Lagos, Nigeria: Role of temperature and rainfall. Academic Journals.

Organization WH (2005). Occupational and Environmental Health Team (2006). WHO Air quality guidelines for particulate matter, ozone, nitrogen dioxide and sulfur dioxide : global update 2005 : summary of risk assessment. World Health Organization. .

Ozoh OB, Okwor TJ, Adetona O, Akinkugbe AO, Amadi CE, Esezobor C, Adeyeye 00, Ojo O, Nwude VN, Mortimer K (2018). Cooking Fuels in Lagos, Nigeria: Factors Associated with Household Choice of Kerosene or Liquefied Petroleum Gas (LPG). International journal of environmental research and public health 15: 641.

Pillarisetti A, Allen T, Ruiz-Mercado I, Edwards R, Chowdhury Z, Garland C, Hill LD, Johnson M, Litton CD, Lam NL, Pennise D, Smith KR (2017). Small, Smart, Fast, and Cheap: Microchip-Based Sensors to Estimate Air Pollution Exposures in Rural Households. Sensors (Basel) 17: 1879.

PrayGod G, Mukerebe C, Magawa R, Jeremiah K, Török ME (2016). Indoor Air Pollution and Delayed Measles Vaccination Increase the Risk of Severe Pneumonia in Children: Results from a Case-Control Study in Mwanza, Tanzania. PloS one 11: e0160804.

Ram PK, Dutt D, Silk BJ, Doshi S, Rudra CB, Abedin J, Goswami D, Fry AM, Brooks WA, Luby SP, Cohen AL (2014). Household air quality risk factors associated with childhood pneumonia in urban Dhaka, Bangladesh. The American journal of tropical medicine and hygiene 90: 968-975. 
Ramanathan N, Khan B, Leong I, Lukac M (2011a). Comparison Between Elemental Carbon Measured Using Thermal-Optical Analysis and Black Carbon Measurements Using a Novel Cellphone-Based System. American Geophysical Union San Francisco, CA.

Ramanathan N, Lukac M, Ahmed T, Kar A, Siva P, Honles T, Leong I, Rehman IH, Schauer J, Ramanathan V (2011b). A cellphone based system for large scale monitoring of black carbon. Atmospheric Environment 45: 4481-4487.

Ranabhat CL, Kim C-B, Kim C-S, Jha N, Deepak KC, Connel FA (2015). Consequence of indoor air pollution in rural area of Nepal: A simplified measurement approach. Frontiers in public health 3: 5.

Rudan I, Boschi-Pinto C, Biloglav Z, Mulholland K, Campbell H (2008). Epidemiology and etiology of childhood pneumonia. Bulletin of the World Health Organization 86: 408-416.

Rumchev K, Spickett J, Bulsara M, Phillips M, Stick S (2004). Association of domestic exposure to volatile organic compounds with asthma in young children. Thorax 59: 746-751.

Sadoh A, Nwaneri D, Famuyiwa O, Ogboghodo B, Eregie C, Oviawe O (2015). Traders' Perception of Cooking Smoke as a Risk Factor for Childhood Pneumonia. Nigerian Journal of Paediatrics 42.

Schwartz J NL (2000). Fine Particles Are More Strongly Associated Than Coarse Particles with Acute Respiratory Health Effects in Schoolchildren. 6.

Semple S, Ibrahim AE, Apsley A, Steiner M, Turner S (2015). Using a new, low-cost air quality sensor to quantify second-hand smoke (SHS) levels in homes. Tobacco Control 24: 153.

Shears RK, Jacques LC, Naylor G, Miyashita L, Khandaker S, Lebre F, Lavelle EC, Grigg J, French N, Neill DR, Kadioglu A (2020). Exposure to diesel exhaust particles increases susceptibility to invasive pneumococcal disease. The Journal of allergy and clinical immunology 145: 1272-1284.e1276. 
Shibata T, Wilson J, Watson L, LeDuc A, Meng C, Ansariadi EY, La Ane R, Manyullei S, Maidin A (2014). Childhood Acute Respiratory Infections and Household Environment in an Eastern Indonesian Urban Setting. International Journal of Environmental Research and Public Health 11: 12190-12203.

Simon AK, Hollander GA, McMichael A (2015). Evolution of the immune system in humans from infancy to old age. Proc Biol Sci 282: 20143085-20143085.

Smith KR, Samet JM, Romieu I, Bruce N (2000). Indoor air pollution in developing countries and acute lower respiratory infections in children. Thorax 55: 518-532.

Sonego M, Pellegrin MC, Becker G, Lazzerini M, Sankoh OA (2015). Risk Factors for Mortality from Acute Lower Respiratory Infections (ALRI) in Children under Five Years of Age in Low and Middle-Income Countries: A Systematic Review and Meta-Analysis of Observational Studies. PloS one 10: e0116380.

Thörn LKAM, Minamisava R, Nouer SS, Ribeiro LH, Andrade AL (2011). Pneumonia and poverty: a prospective population-based study among children in Brazil. BMC infectious diseases 11: 180-180.

Tofful L, Perrino C (2015). Chemical Composition of Indoor and Outdoor PM2.5 in Three Schools in the City of Rome. Atmosphere 6.

Troeger C, Blacker B, Khalil IA, Rao PC, Cao J, Zimsen SRM, Albertson SB, Deshpande A, Farag T, Abebe Z, Adetifa IMO, Adhikari TB, Akibu M, Al Lami FH, Al-Eyadhy A, Alvis-Guzman N, Amare AT, Amoako YA, Antonio CAT, Aremu O, Asfaw ET, Asgedom SW, Atey TM, Attia EF, Avokpaho EFGA, Ayele HT, Ayuk TB, Balakrishnan K, Barac A, Bassat Q, Behzadifar M, Behzadifar M, Bhaumik S, Bhutta ZA, Bijani A, Brauer M, Brown A, Camargos PAM, Castañeda-Orjuela CA, Colombara D, Conti S, Dadi AF, Dandona L, Dandona R, Do HP, Dubljanin E, Edessa D, Elkout H, Endries AY, Fijabi DO, Foreman KJ, Forouzanfar MH, Fullman N, GarciaBasteiro AL, Gessner BD, Gething PW, Gupta R, Gupta T, Hailu GB, Hassen HY, Hedayati MT, Heidari M, Hibstu DT, Horita N, Ilesanmi OS, Jakovljevic MB, Jamal AA, Kahsay A, Kasaeian A, Kassa DH, Khader YS, Khan EA, Khan MN, Khang Y-H, Kim YJ, Kissoon N, Knibbs LD, Kochhar S, Koul PA, Kumar GA, Lodha R, Magdy Abd El Razek H, Malta DC, Mathew JL, Mengistu DT, Mezgebe HB, Mohammad KA, Mohammed MA, Momeniha F, Murthy S, Nguyen CT, Nielsen KR, Ningrum DNA, Nirayo YL, Oren E, Ortiz JR, Pa M, Postma MJ, Qorbani M, Quansah R, Rai RK, Rana SM, Ranabhat CL, Ray SE, Rezai MS, Ruhago GM, Safiri S, Salomon JA, Sartorius B, Savic M, Sawhney M, She J, Sheikh A, Shiferaw MS, Shigematsu M, Singh JA, Somayaji R, Stanaway JD, 
Sufiyan MB, Taffere GR, Temsah M-H, Thompson MJ, Tobe-Gai R, Topor-Madry R, Tran BX, Tran TT, Tuem KB, Ukwaja KN, Vollset SE, Walson JL, Weldegebreal F, Werdecker A, West TE, Yonemoto N, Zaki MES, Zhou L, Zodpey S, Vos T, Naghavi M, Lim SS, Mokdad AH, Murray CJL, Hay SI, Reiner RC, Jr. (2018). Estimates of the global, regional, and national morbidity, mortality, and aetiologies of lower respiratory infections in 195 countries, 1990\&\#x2013;2016: a systematic analysis for the Global Burden of Disease Study 2016. The Lancet Infectious Diseases 18: 1191-1210.

Tyrer S, Heyman B (2018). Sampling in epidemiological research: issues, hazards and pitfalls. BJPsych Bulletin 40: 57-60.

UNICEF (2016). One is too many: ending child deaths from pneumonia and diarrhoea.

UNICEF (2019). UNICEF analysis based on WHO and Maternal and Child Epidemiology Estimation Group interim estimates produced in September 2019, applying cause fractions for the year 2017 to United Nations Inter-Agency Group for Child Mortality Estimation estimates for the year 2018; Convention on the Rights of the Child

Usman R, Sheu A (2010). Correlates and health on consequences of indoor air pollution among urban households in Ilorin, Nigeria. Glob J Hum Soc Sci 10: 80-87.

Walker CLF, Rudan I, Liu L, Nair H, Theodoratou E, Bhutta ZA, O'Brien KL, Campbell H, Black RE (2013). Global burden of childhood pneumonia and diarrhoea. Lancet (London, England) 381: 1405-1416.

WHO (2016a). Air pollution levels rising in many of the world's poorest cities: WHO.

WHO (2016b). Ambient air pollution: A global assessment of exposure and burden of disease

WHO (2017). WHO indoor air quality guidelines: household fuel combustion: WHO. 
WHO (2019). Pneumonia: World Health Organisation.

Wittkowski KM, Song T (2010). Nonparametric methods for molecular biology. Methods in molecular biology. 105-153.

Woolson RF (2008). Wilcoxon Signed-Rank Test. In Wiley Encyclopedia of Clinical Trials.

Yang B-Y, Qian Z, Li S, Fan S, Chen G, Syberg KM, Xian H, Wang S-Q, Ma H, Chen D-H, Yang M, Liu K-K, Zeng X-W, Hu L-W, Guo Y, Dong G-H (2018). Long-term exposure to ambient air pollution (including PM1) and metabolic syndrome: The 33 Communities Chinese Health Study (33CCHS). Environmental Research 164: 204-211.

Zajusz-Zubek E, Radko T, Mainka A (2017). Fractionation of trace elements and human health risk of submicron particulate matter (PM1) collected in the surroundings of coking plants. Environmental Monitoring and Assessment 189: 389.

Zar HJ, Ferkol TW (2014). The global burden of respiratory disease-impact on child health. Pediatr Pulmonol 49: 430-434.

Zhang L, Masui M, Mizukoshi H, Ninomiya Y, Kanaoka C (2007). Formation of Submicron Particulates (PM1) from the Oxygen-Enriched Combustion of Dried Sewage Sludge and Their Properties. Energy \& Fuels 21: 8898.

\section{Tables}


Table 1

Sociodemographic characteristics of the study population, Abuja, Nigeria $($ Cases $=150$, Controls $=140)$ Chi square .

\begin{tabular}{|c|c|c|c|}
\hline Characteristics & \multicolumn{3}{|c|}{ Cases (150)Controls (140)p-value } \\
\hline \multicolumn{4}{|l|}{ Age, Months } \\
\hline $0-6(\%)$ & $17(11.33)$ & $20(14.29)$ & \\
\hline $7-12(\%)$ & $40(26.67)$ & 19 (13.57) & \\
\hline $13-24(\%)$ & $41(27.33)$ & $31(22.14)$ & \\
\hline \multirow[t]{2}{*}{$25-59(\%)$} & $51(34)$ & $64(45.71)$ & \\
\hline & & & 0.079 \\
\hline \multicolumn{4}{|l|}{ Sex } \\
\hline Male (\%) & $56(37.33)$ & $87(62.14)$ & \\
\hline Female (\%) & $94(62.67)$ & $53(37.86)$ & 0.000 \\
\hline \multicolumn{4}{|c|}{ Socio-economic status } \\
\hline Low & $76(50.67)$ & $54(38.57)$ & \\
\hline Middle & $57(38)$ & $70(50)$ & \\
\hline High & $17(11.33)$ & $16(11.43)$ & 0.090 \\
\hline \multicolumn{4}{|c|}{ Household Income per month ( } \\
\hline $0-20,000$ & $4(2.67)$ & $10(7.14)$ & \\
\hline $20,001-100,000$ & $86(57.33)$ & $105(75)$ & \\
\hline $100,001-500,000$ & $53(35.33)$ & $19(13.57$ & \\
\hline $500,001-1,000,000$ & $3(2)$ & $4(2.86)$ & \\
\hline$>1,000,000$ & $0(0)$ & $1(0.71)$ & \\
\hline Missing & $4(2.67)$ & $1(0.71)$ & 0.000 \\
\hline \multicolumn{4}{|l|}{ Immunization } \\
\hline Yes & $141(94)$ & $138(98.57)$ & \\
\hline No & $6(4)$ & $1(0.71)$ & \\
\hline
\end{tabular}




\begin{tabular}{|llll|}
\hline Characteristics & \multicolumn{1}{c|}{ Cases (150)Controls (140)p-value } \\
\hline Missing & $3(2)$ & $1(0.71)$ & 0.115 \\
MUAC & & & \\
Green & $88(58.67)$ & $108(77.14)$ & \\
Red & $62(41.33)$ & $32(22.86)$ & 0.001 \\
\hline
\end{tabular}


Table 2

Lifestyle factors affecting exposure to pollutants. (Cases $=150$, Controls $=140)$ Chi square.

\begin{tabular}{|c|c|c|c|}
\hline Characteristics & \multicolumn{3}{|c|}{ Cases (150)Controls (140) $P$-value } \\
\hline \multicolumn{4}{|l|}{ Child present during cooking } \\
\hline Yes & $113(75.33)$ & $52(37.14)$ & \\
\hline No & $28(18.66)$ & $83(59.29)$ & 0.000 \\
\hline Sometimes & $3(2)$ & $0(0)$ & \\
\hline \multicolumn{4}{|l|}{ Main cooking fuel } \\
\hline Woods & $10(6.71)$ & $13(9.35)$ & \\
\hline Charcoal & $8(5.37)$ & $3(2.16)$ & \\
\hline Kerosene & $18(12.08)$ & $28(20.14)$ & \\
\hline Electricity & $7(4.70)$ & $4(2.88)$ & \\
\hline Liquid petroleum gas (LPG) & $43(28.86)$ & $31(22.30)$ & \\
\hline Bio-gas & $21(14.09)$ & $24(17.27)$ & \\
\hline Fuel combinations & $41(27.52)$ & $36(25.90)$ & \\
\hline No reply & $1(0.67)$ & $0(0)$ & 0.268 \\
\hline \multicolumn{4}{|l|}{ Roof Materials } \\
\hline Local sources & $1(0.67)$ & $0(0)$ & \\
\hline Tiles, slate, shingle & $17(11.33)$ & $16(11.43)$ & \\
\hline Zinc, Iron or other metal sheets & $126(84)$ & $121(86.43)$ & \\
\hline Asbestos cement sheets & $2(1.33)$ & $0(0)$ & \\
\hline Other material & $0(0)$ & $2(1.43)$ & \\
\hline Don't know & $3(2)$ & $0(0)$ & 0.168 \\
\hline \multicolumn{4}{|l|}{ Floor Material } \\
\hline Mud/dirt & $2(1.33)$ & $2(1.43)$ & \\
\hline Brick, stone \& lime & $2(1.33)$ & $0(0)$ & \\
\hline
\end{tabular}




\begin{tabular}{|c|c|c|c|}
\hline Characteristics & \multicolumn{3}{|c|}{ Cases (150)Controls (140) $P$-value } \\
\hline Cement & $75(50)$ & $74(52.86)$ & \\
\hline Mosaic/tiles & $64(42.67)$ & $61(43.57)$ & \\
\hline Other materials & $2(1.33)$ & $0(0)$ & \\
\hline Combination & $3(2)$ & $2(1.43)$ & \\
\hline No reply & $1(0.67)$ & $0(0)$ & 0.552 \\
\hline \multicolumn{4}{|l|}{ Wall materials } \\
\hline Mud/dirt & 28 (18.67) & $30(21.43)$ & \\
\hline Unburnt bricks & $4(2.67)$ & $8(5.71)$ & \\
\hline Stone & $3(2)$ & $1(0.71)$ & \\
\hline Cement concrete & 109 (72.67) & $98(70)$ & \\
\hline Combination & $1(0.67)$ & $2(1.43)$ & \\
\hline No reply & $3(2)$ & $0(0)$ & 0.302 \\
\hline \multicolumn{4}{|c|}{ Number of windows and major openings in house } \\
\hline $0-2$ & $69(46)$ & $50(35.71)$ & \\
\hline $3-5$ & $64(42.67)$ & $64(45.71)$ & \\
\hline $6-8$ & $11(7.33)$ & $15(10.71)$ & \\
\hline $9-13$ & $3(2)$ & $6(4.29)$ & 0.246 \\
\hline \multicolumn{4}{|c|}{ Number of windows in Kitchen } \\
\hline 0 & $50(35.46)$ & $9(7.63)$ & \\
\hline 1 & $82(58.16)$ & $88(74.58)$ & \\
\hline 2 & $5(3.55)$ & $14(11.86)$ & \\
\hline 3 & $0(0)$ & $2(1.69)$ & \\
\hline 5 & $0(0)$ & $1(0.85)$ & \\
\hline No reply & $1(0.71)$ & $4(3.39)$ & \\
\hline
\end{tabular}




\begin{tabular}{|llll|}
\hline Characteristics & \multicolumn{3}{c|}{ Cases (150)Controls (140) $P$-value } \\
\hline Don't know & $2(1.42)$ & $0(0)$ & 0.000 \\
Not applicable & $1(0.71)$ & $0(0)$ & \\
\hline
\end{tabular}


Table 3

Estimated burden of pneumonia in children under five within study setting (January 2018 - January 2019) JanuaryFebruaryMarchAprilMay June JulyAugustSeptemberOctoberNovemberDecemberJanuary

\section{General}

Hospitals

\begin{tabular}{|c|c|c|c|c|c|c|c|c|c|c|c|c|}
\hline 1 & 0 & 0 & 0 & 0 & 3 & 4 & 0 & 0 & 2 & 7 & 4 & 0 \\
\hline 2 & 1 & 0 & 0 & 0 & 0 & 0 & 2 & 0 & 1 & 8 & 0 & 0 \\
\hline 3 & 0 & 1 & 1 & 0 & 0 & 0 & 1 & 1 & 1 & 0 & 1 & 7 \\
\hline 4 & 0 & 0 & 0 & 0 & 7 & 0 & 7 & 0 & 0 & 9 & 0 & 1 \\
\hline 5 & 0 & 0 & 0 & 0 & 0 & 0 & 0 & 0 & 0 & 0 & 0 & 0 \\
\hline 6 & 0 & 0 & 7 & 0 & 0 & 5 & 2 & 0 & 5 & 4 & 5 & 5 \\
\hline 7 & 2 & 0 & 0 & 1 & 2 & 0 & 1 & 2 & 2 & 0 & 0 & 2 \\
\hline 8 & 0 & 0 & 0 & 0 & 1 & 1 & 2 & 2 & 2 & 3 & 3 & 4 \\
\hline 9 & 0 & 0 & 0 & 7 & 0 & 1 & 0 & 3 & 4 & 3 & 0 & 0 \\
\hline 10 & 0 & 0 & 0 & 0 & 0 & 0 & 5 & 0 & 7 & 5 & 7 & 1 \\
\hline 11 & 0 & 0 & 1 & 1 & 5 & 2 & 3 & 5 & 6 & 7 & 10 & 4 \\
\hline
\end{tabular}

Public Health

Centres

$(\mathrm{PHC})$

\begin{tabular}{|llllllllllllll|}
1 & 0 & 7 & 1 & 0 & 0 & 0 & 2 & 2 & 2 & 6 & 4 & 1 & 0 \\
\hline 3 & 0 & 0 & 0 & 1 & 1 & 2 & 1 & 6 & 0 & 2 & 7 & 1 & 5 \\
\hline 4 & 0 & 0 & 0 & 5 & 2 & 7 & 2 & 5 & 6 & 0 & 0 & 3 & 0 \\
\hline 5 & 0 & 0 & 0 & 0 & 0 & 1 & 0 & 2 & 0 & 1 & 0 & 3 & 1 \\
\hline 7 & 0 & 5 & 3 & 2 & 2 & 1 & 3 & 7 & 4 & 2 & 3 & 1 & 1 \\
\hline Total & 0 & 2 & 3 & 3 & 0 & 2 & 5 & 5 & 3 & 2 & 5 & 4 & 0 \\
\hline & 10 & 1 & 2 & 3 & 2 & 1 & 0 & 0 & 2 & 0 & 0 & 2 & 0 \\
\hline
\end{tabular}


Table 4

Summary data showing the comparison of the $\mathrm{PM}_{2.5}, \mathrm{CO}, \mathrm{PM}_{1}$ and $\mathrm{BC}$ in matched $(\mathrm{N})$ cases and control at particular time points.

\begin{tabular}{|c|c|c|c|c|c|c|c|c|c|c|c|c|}
\hline \multicolumn{4}{|c|}{ Variables 3 hours (10am - 5 pm) } & \multicolumn{3}{|c|}{10 hours (3am - 2 pm) } & \multicolumn{3}{|c|}{15 hours (3am - 5 pm) } & \multicolumn{3}{|c|}{$20-24$ hours } \\
\hline & $\begin{array}{l}\text { Case } \\
\text { mean } \\
\text { (n) }\end{array}$ & $\begin{array}{l}\text { Control } \\
\text { mean }(n)\end{array}$ & $\begin{array}{l}\mathrm{P} \\
\text { Value }\end{array}$ & $\begin{array}{l}\text { Case } \\
\text { mean } \\
(n)\end{array}$ & $\begin{array}{l}\text { Control } \\
\text { mean (n) }\end{array}$ & $\begin{array}{l}\mathrm{P} \\
\text { Value }\end{array}$ & $\begin{array}{l}\text { Case } \\
\text { mean } \\
(n)\end{array}$ & $\begin{array}{l}\text { Control } \\
\text { mean (n) }\end{array}$ & $\begin{array}{l}\mathrm{P} \\
\text { Value }\end{array}$ & $\begin{array}{l}\text { Case } \\
\text { mean } \\
(n)\end{array}$ & $\begin{array}{l}\text { Control } \\
\text { mean }(n)\end{array}$ & $\begin{array}{l}P \\
\text { Value }\end{array}$ \\
\hline $\begin{array}{l}\mathrm{PM}_{2.5} \\
(\mu \mathrm{g} / \mathrm{m} 3)\end{array}$ & $\begin{array}{l}51.87 \\
(110)\end{array}$ & $\begin{array}{l}105.06 \\
(112)\end{array}$ & 0.0533 & $\begin{array}{c}3129.3 \\
(111)\end{array}$ & $\begin{array}{l}176.97 \\
(112)\end{array}$ & 0.0147 & $\begin{array}{r}7100.2 \\
(112)\end{array}$ & $\begin{array}{l}162.3 \\
(112)\end{array}$ & 0.0111 & $\begin{array}{r}1117.4 \\
(112)\end{array}$ & $\begin{array}{l}174.4 \\
(111)\end{array}$ & 0.0296 \\
\hline $\begin{array}{l}\mathrm{CO} \\
(\mu \mathrm{g} / \mathrm{m} 3)\end{array}$ & $\begin{array}{l}2700 \\
(110)\end{array}$ & $\begin{array}{l}1730 \\
(112)\end{array}$ & 0.3527 & $\begin{array}{l}72270 \\
(111)\end{array}$ & $\begin{array}{l}2930 \\
(112)\end{array}$ & 0.3251 & $\begin{array}{r}12340 \\
(112)\end{array}$ & $\begin{array}{l}2700 \\
(112)\end{array}$ & 0.3269 & $\begin{array}{r}91950 \\
(112)\end{array}$ & $\begin{array}{l}2810 \\
(111)\end{array}$ & 0.0729 \\
\hline $\begin{array}{l}\mathrm{PM}_{1} \\
(\mu \mathrm{g} / \mathrm{m} 3)\end{array}$ & $\begin{array}{l}50.04 \\
(112)\end{array}$ & $\begin{array}{l}123.9 \\
(112)\end{array}$ & 0.0653 & $\begin{array}{l}362.13 \\
(112)\end{array}$ & $\begin{array}{l}91.06 \\
(112)\end{array}$ & 0.3545 & $\begin{array}{r}565.19 \\
(112)\end{array}$ & $\begin{array}{l}85.95 \\
(112)\end{array}$ & 0.6163 & $\begin{array}{r}361.26 \\
(112)\end{array}$ & $\begin{array}{l}94.39 \\
(111)\end{array}$ & 0.1819 \\
\hline $\begin{array}{l}B C \\
(\mu g / m 3)\end{array}$ & & & & & & & & & & $\begin{array}{l}4350.5 \\
(132)\end{array}$ & $\begin{array}{l}4126.3 \\
(123)\end{array}$ & 0.0260 \\
\hline $\begin{array}{l}\text { Note that } \\
\text { there was }\end{array}$ & $\begin{array}{l}\text { t BC wa } \\
\text { s a stati }\end{array}$ & $\begin{array}{l}\text { a single } n \\
\text { stically sig }\end{array}$ & $\begin{array}{l}\text { neasure } \\
\text { nificant }\end{array}$ & $\begin{array}{l}\text { ement } s \\
t \text { differe }\end{array}$ & howing the & $\begin{array}{l}\text { averag } \\
\text { en case }\end{array}$ & $\begin{array}{l}\text { ye for a } \\
\text { es and c }\end{array}$ & $24 \mathrm{~h}$ perioc & d. Bold $t$ & $\begin{array}{l}\text { figures } \\
\text { Im test, }\end{array}$ & $\begin{array}{l}\text { show whe } \\
P \text { value }<C\end{array}$ & $\begin{array}{l}\text { ere } \\
0.05) \text {. }\end{array}$ \\
\hline
\end{tabular}


Table 5

Summary data showing the comparison of the $\mathrm{PM}_{2.5}, \mathrm{CO}, \mathrm{PM}_{1}$ and $\mathrm{BC}$ in cases and control divided by season and mode of diagnosis.

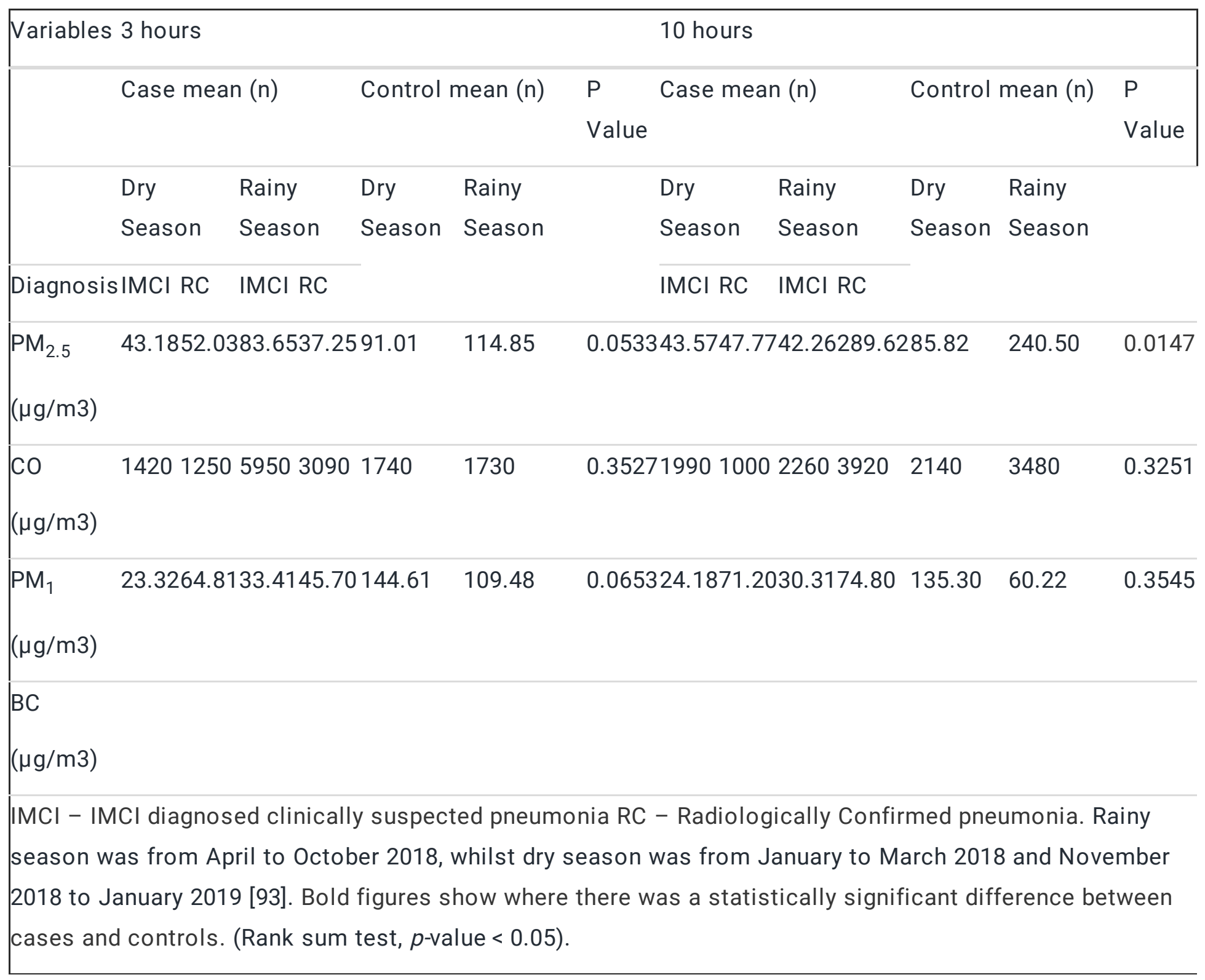




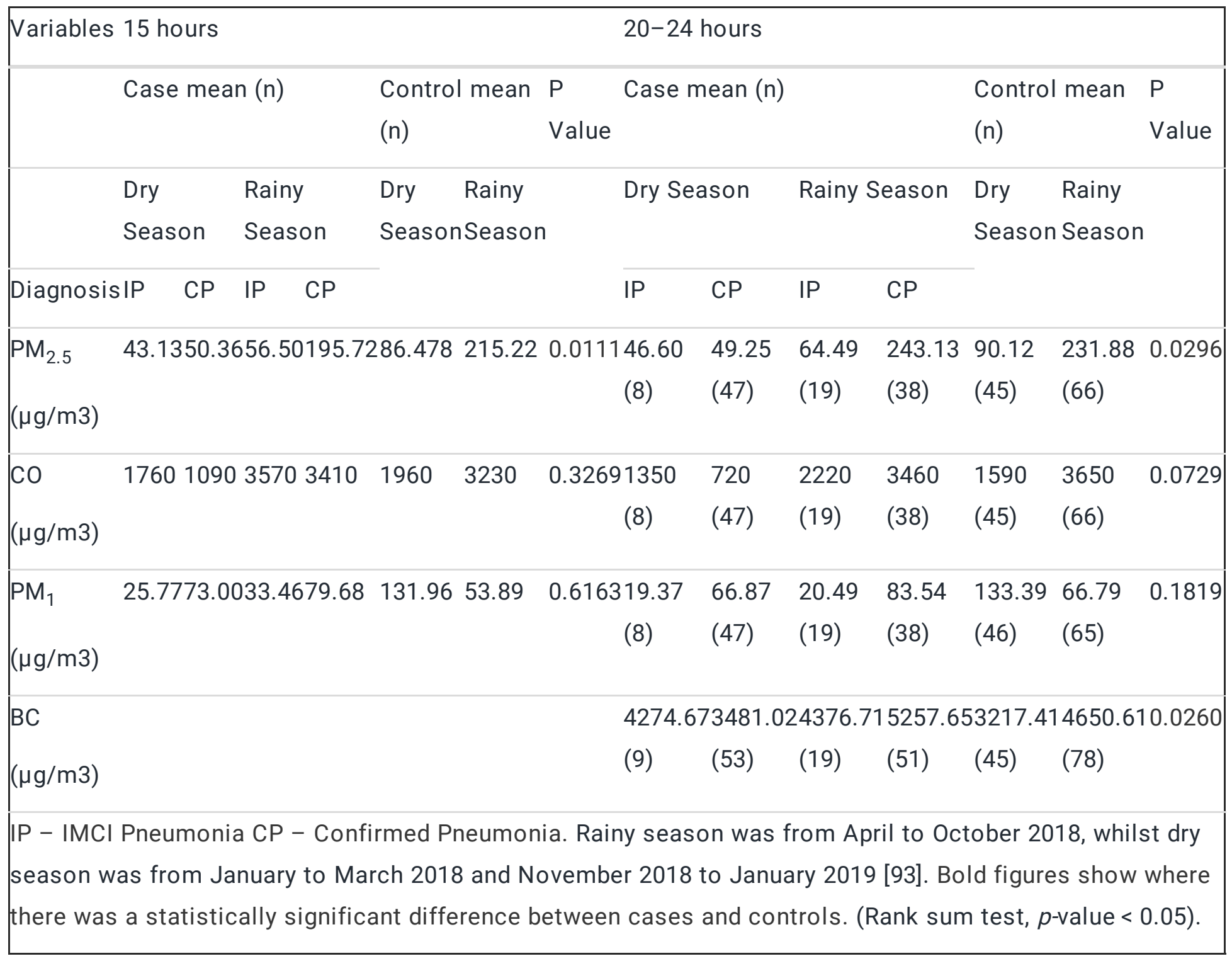

\section{Figures}




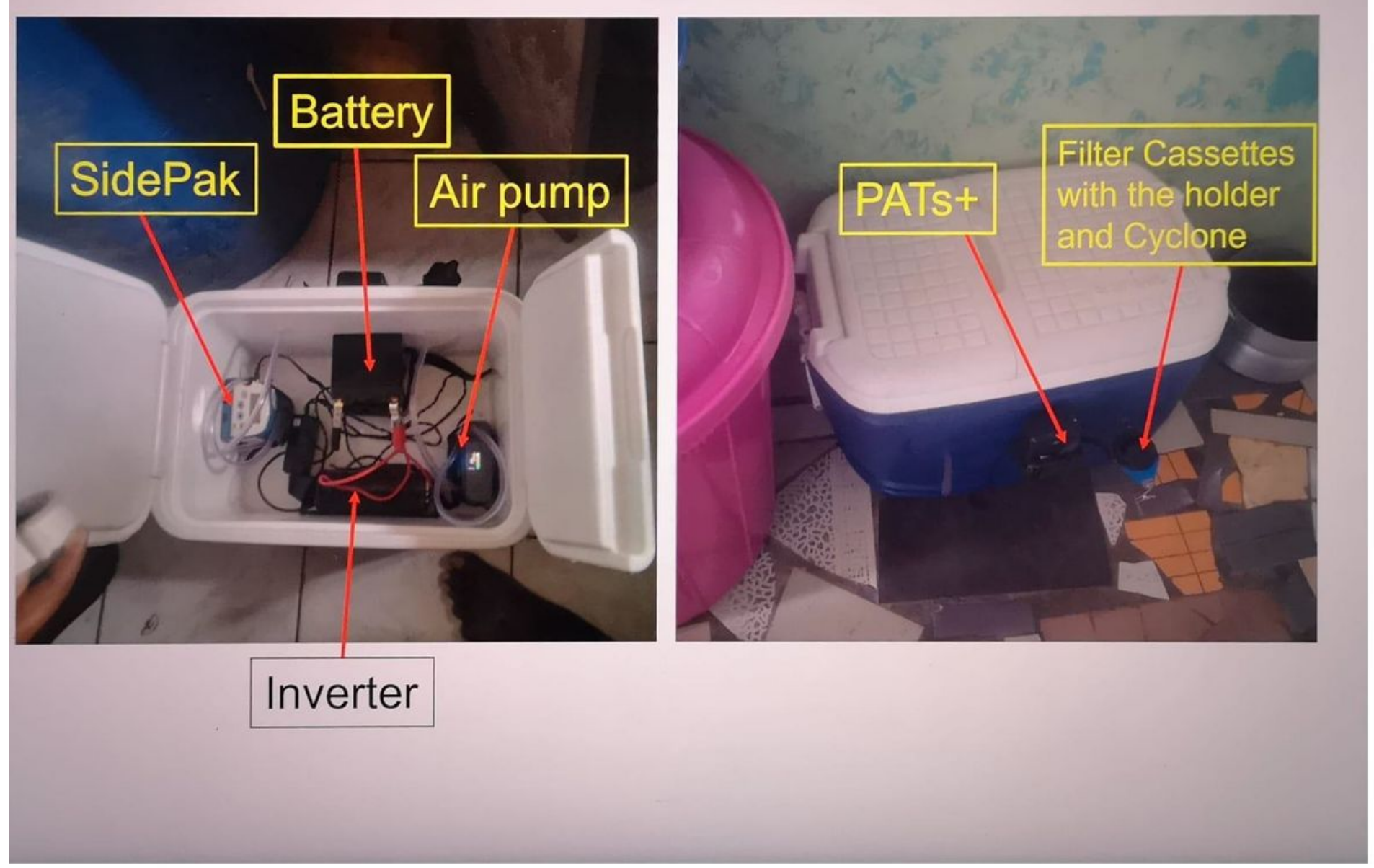

Figure 1

Equipment setup for indoor air measurements (Picture Credit: Author). 
A
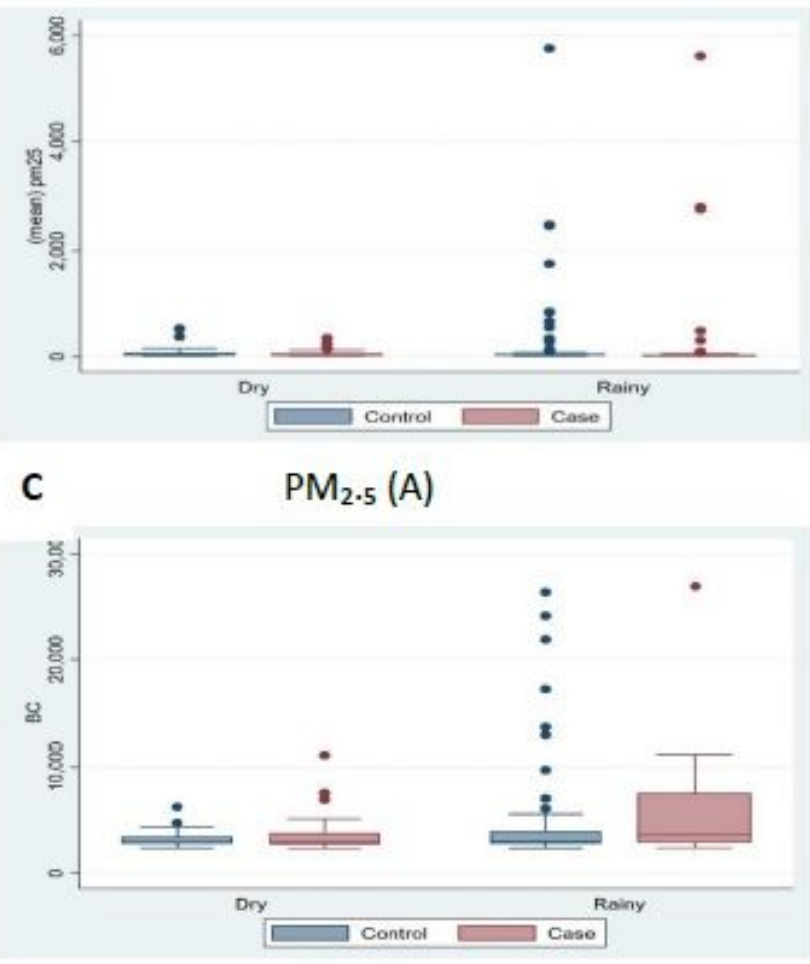

$\mathrm{BC}(\mathrm{A})$
B
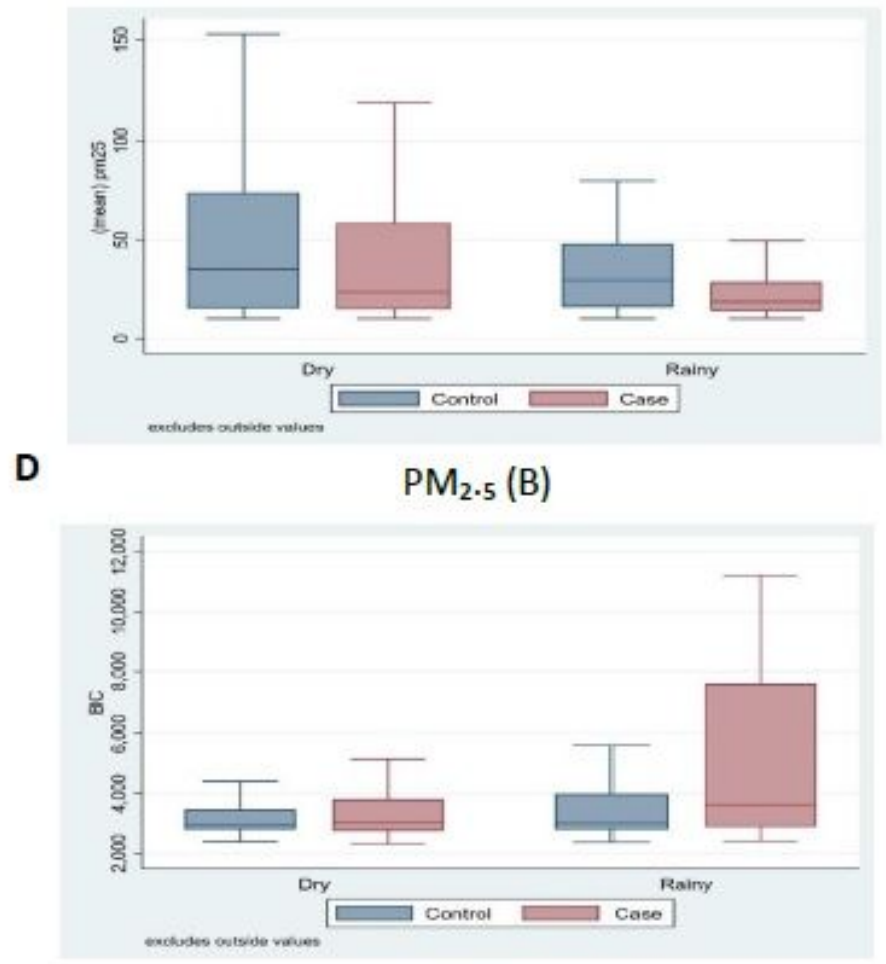

$\mathrm{BC}(\mathrm{B})$

\section{Figure 2}

Box plots of PM2.5 and Black carbon (BC) distributions over 20 to 24 hours. The horizontal line in each box represents the median value and the top and bottom of the box represent the 25th and 75th percentile, with the lines extending from the top and bottom of the boxes widening to the 5th and 95th percentile of the

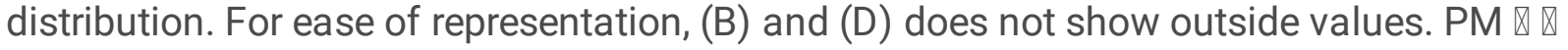

